\title{
Evaluation on Sustainable Development of Urban Agglomeration under the New Urbanization and the Industrial Structure Upgraded Based on a Case Study of Beibu Gulf Urban Agglomeration
}

\author{
Haili Huang* \\ School of Business Administration, Zhongnan University of Economics and Law, Wuhan, Hubei, China \\ *Corresponding Author.
}

\begin{abstract}
The new urbanization has a connotation of human-centered urbanization, covering the synchronization of informatization, industrialization, agricultural modernization and urbanization, the optimization of layout, ecological civilization, cultural inheritance, and the realization of balanced and sustainable development among population, economy, society, resources and environment. Taking the path of new urbanization is the development direction of Chinese cities in the future. It is an important measure taken by the Chinese government to implement the new concept of development to promote the optimization and upgrading of the industrial structure and achieve balanced development between ecological and ecological protection and economic and social development. In this paper, firstly, based on the relevant theories of urbanization at home and abroad, the evaluation index system of urban sustainable development is constructed in five dimensions: economic market driving force, population and social development force, resources and environment carrying capacity, public service guarantee force, and urban-rural integration and aggregation force to study the cities and counties in the Beibu Gulf urban agglomeration region. Then, the factor analysis method is used to perform sub-item and comprehensive evaluation on the urban sustainable development capability. Finally, combined with the development characteristics of each city in the urban agglomeration, relevant development strategies and suggestions are put forward to provide reference for the development of urbanization.
\end{abstract}

Keywords: New urbanization, Industrial structure upgraded, Beibu Gulf urban agglomeration, Sustainable development, Empirical research

\section{Introduction}

Urbanization is the only way for economic and social development, and its development level has a profound impact on the economic development and layout of a country (region). However, in the process of urbanization, problems such as unbalanced development between regions, large gap between urban and rural areas, ecological degradation, environmental pollution, resource depletion, etc. have become increasingly prominent, which bring challenges to the traditional urbanization model for transformation. China's traditional industrial industry is still the main body of the industrial economy, the industrial industry development and the acceleration of the urbanization process are facing the challenge of coordination. Taking urban agglomeration as the main form of development is the requirement of new urbanization in China. Specifically, in the report of the 19th National Congress of the Communist Party of China, it is proposed that urban agglomeration should be taken as the main body to build a coordinated development pattern of large, medium and small cities and small towns, so as to speed up the urbanization of agricultural transfer population. The evaluation and study of urban sustainable development under the new urbanization and the Industrial structure upgraded based on the element of urban agglomeration is aimed at providing ideas for the subsequent sustainable development path, which will have a realistic guiding significance for the advancement of new urbanization in China.

The new urbanization is essentially people-oriented, with the core of balanced and sustainable development. It emphasizes the transformation of the mode of development and the building of a livable city through spatial distribution and enhancement of the carrying capacity of economy, infrastructure, public services, resources and environment for the population. Optimizing and upgrading the industrial structure to reduce the consumption of ISSN: 0010-8189 
resources, reduce environmental pollution and give full play to the advantages of human resources is the direction of China's industrial development. The Chinese government has proposed to adopt more powerful policies and measures, strive to reach the value of carbon dioxide emissions by 2030 , strive to achieve carbon neutrality by 2060, promote the important transformation of the country from industrial civilization to ecological civilization, industrial structure optimization and upgrading is the inevitable trend.Fan Hongjie et al. (2013) believed that urbanization is a people-centered process in which factors of production gather in cities, including the transformation and replacement of two major systems, i.e., software and hardware, in economy, society and infrastructure [1]. Mohammad Baydoun (2013) argued that the sustainable development of cities requires social, economic and ecological consistency, and sustainable development needs to protect the existing local economy and better distribute benefits [2].

Because of the different systems at home and abroad, according to the weight of government and market mechanism in urbanization, the urban development model can be divided into government-led or market-led. Roberta Capello and Roberto Camagn (2000) held that the best city scale depends largely on what and how the city produces and the way of cooperation within the city system, and the city scale, its specialization and integration with the city system affect the location cost and benefit [3]. Didier Desponds and Elizabeth Auclair (2017) believed that new towns must have their own economic attraction, and most importantly improve their innovative ability, because they must attract not only new residents but also populations composed of different social forms [4]. Lu Ming (2016) held that urbanization should be market-oriented and eventually balanced in aggregation through market adjustment and aggregation of production elements, thus solving social problems in the development of urbanization [5]. Han Hong et al. (2019) believed that the key to urbanization is not speed but quality and efficiency, so urbanization should also include the ecological environment and people's daily life [6].

According to the National New Urbanization Plan (2014-2020), new urbanization is evaluated by 18 indicators from four levels: urbanization level, basic public services, infrastructure, resources and environment. Han Zhaozhou et al. (2013) thought that new urbanization requires coordinated development of economy, resources, population and environment, so the evaluation system of new urbanization was constructed from five dimensions: economic level and structure, scientific and technological progress and population resources, ecological environment and natural resources, urban-rural integration and social harmony [7]. Éva Kovacs (2016) identified 28 indicators of urban vitality evaluation system from five aspects: economic development, education and management, residents' participation in social activities, human resources factors and innovative subjects [8]. On the whole, the existing index systems for sustainable development of urbanization are different in evaluation dimensions and index selection, which often cannot fully reflect the aspects that need to be evaluated for sustainable development of urbanization. Therefore, more attention should be paid to environmental governance, human development, urban-rural harmony and other key issues. New urbanization, a major topic, is the only way to realize a well-off society and modernization in our country. The sustainable research on the new urbanization with urban agglomeration as the competitive unit model still needs continuous in-depth exploration and analysis.

Beibu Gulf urban agglomeration is an strategic stronghold of China's "Maritime Silk Road" and the "Belt and Road Initiative" for ASEAN countries, including Nanning, Beihai, Qinzhou, Fangchenggang, Yulin and Chongzuo cities in Guangxi, Zhanjiang, Maoming and Yangjiang cities in Guangdong and Haikou, Danzhou, Dongfang cities, and Chengmai, Lingao and Changjiang counties in Hainan, has a land area of 116,600 square kilometers and two free trade zones in Hainan and Guangxi. At the end of 2018, the resident population of Beibu Gulf urban agglomeration was 42.251 million, and the regional GDP was 1,974.601 billion yuan. The analysis of the relevant factors that affect the sustainable development of the new urbanization after studying the Beibu Gulf urban agglomeration as one of the key urban agglomerations of the national new urbanization construction in 2020 has certain guiding significance for correctly understanding the sustainable development law of the urban agglomeration model urbanization and guiding the practice of the sustainable development of urbanization in other regions.

\section{Establishment of Evaluation Index System and Evaluation Method}




\subsection{Establishment of evaluation indicator system}

People are the core of new urbanization, which requires the synchronization of informationization, industrialization, agricultural modernization and urbanization, and realizes the balanced and sustainable development among population, economy, society, resources and environment, which will be the inevitable development trend of urbanization in China. In this paper, according to the five principles of scientificity, systematicness, comparability, operability and dynamics, combined with the main connotation of new urbanization, based on the main indicators of new urbanization in China, the sustainable development evaluation system of new urbanization with 40 indicators is constructed from five dimensions: economic drive, population and social development, resource and environment bearing, public service guarantee and urban-rural integration and agglomeration with the concept of sustainable development throughout. See Table 1 for the specific indicator system.

\subsection{Evaluation methodology and steps}

\subsubsection{Factor analysis}

In this paper, the factor analysis method is used to comprehensively evaluate the sustainable development of new urbanization, which is expressed by the following mathematical model:

$$
x_{i}=a_{i 1} F_{i 1}+a_{i 2} F_{i 2} \cdots+a_{i m} F_{i m}+\varepsilon_{i}(\mathrm{i}=1,2 \ldots, \mathrm{k})
$$

The matrix form of the model is $\mathrm{X}=\mathrm{AF}+a \varepsilon$

Where,

$x_{i}=$ the original indicator variable;

$\mathrm{F}=$ the common factor;

$\varepsilon_{i}=$ the special factor, which indicates the part that cannot be explained by the common factor;

$a_{i j}=$ the factor loading, which is the load of $\mathrm{i}$ variables in $\mathrm{j}$ common factors $(\mathrm{i}=1,2, \mathrm{k} ; \mathrm{j}=1,2, \ldots, \mathrm{m})$.

\subsubsection{Basic steps of factor analysis}

Isotropic treatment of indicators: the sign of positive indicators remains unchanged, while the inverse indicators are replaced by the reciprocals of the indicators.

The formula for standardizing the original sample data is as follows:

$$
Z_{i}=\left(x_{i}-\bar{x}\right) / \mathrm{S}
$$

Where,

$Z_{i}=$ the standardized values;

$x_{i}=$ the original values of sample data;

$\mathrm{S}=$ the standard deviation of sample data.

Calculating correlation coefficient matrix R: The correlation coefficient matrix is established by using standardized data to analyze the correlation between variables and judge whether it is appropriate to do factor analysis. The matrix with $m$ samples and $n$ indicators is established $X=(x i j) m \times n(i=1,2 \ldots, m ; j=1,2, \ldots, n)$ :

$$
\mathrm{X}=\left(\begin{array}{ccc}
x_{11} & \cdots & x_{1 n} \\
\vdots & \cdots & \vdots \\
x_{m 1} & \cdots & x_{m n}
\end{array}\right)
$$

ISSN: 0010-8189 
Factor extraction: Principal component analysis method is used to extract the principal components with the eigenvalue greater than or equal to 1 as the initial common factor.

Factor rotation: The maximum variance method is used to rotate the factor, and the factor load matrix is obtained.

Factor score is calculated. The score $f$ formula of factor $P$ for $\mathrm{n}$ variables is as follows:

$$
f_{p}=w_{p 1} x_{1}+w_{p 2} x_{2} \ldots+w_{p n} x_{n}
$$

For the factor scores with m samples, the formula is as follows:

$$
f_{p m}=\sum w_{p n} x_{n m}
$$

Where,

$f_{p m}=$ the value of $p$ factors on m samples;

$x_{n m}=$ the value of $\mathrm{n}$ variables on $\mathrm{m}$ samples;

$w_{p n}=$ the score coefficient between the $\mathrm{P}$ factor and the $\mathrm{n}$ variables.

For calculating the comprehensive evaluation score, on the basis of calculating the score of each correlation factor, the comprehensive score of the city is calculated by using the variance contribution ratio of each factor as the weight factor, as shown in the annex. The formula is as follows:

$$
\mathrm{F}=\frac{1}{\sum \lambda_{p}} \sum \lambda_{p} F_{p}
$$

Where,

$p=p$ factors;

$\lambda_{p}=$ the weight of the eigenvalues of the $p$ factors;

$F_{p}=$ the standardized factor score of $p$ factors.

\section{An Empirical Study on the Sustainable Development of Beibu Gulf Urban Agglomeration}

\subsection{Collection of sample data}

15 cities (counties) in the Beibu Gulf urban agglomeration are selected as the samples for empirical research. The original data of the selected samples are mainly from Guangxi Statistical Yearbook 2019, Guangdong Statistical Yearbook 2019, Hainan Statistical Yearbook 2019 and relevant official websites.

\subsection{Evaluation on the sustainable development capacity of new urbanization}

3.2.1 Evaluation on the sustainable development ability of new urbanization of urban sub-items Firstly, spss24.0 is used to deal with the sustainable development capability of five dimensions of new urbanization sub-items. For example, according to the test results of KMO and Bartlett, the KMO value of economic market driving force is 0.627 , greater than 0.5 , and the Sig value is 0.006 , less than the significant level of 0.05 , indicating that there is a correlation between the variables, so it is suitable for factor analysis. According to the principle that the cumulative contribution rate is greater than $70 \%$ and the eigenvalue is greater than 1 , two common factors are selected as the comprehensive index variables for evaluating the driving force of economic market, and their cumulative contribution rate is $70.181 \%$. The results are shown in Table 2. 
The maximum variance rotation method is used to obtain the rotated factor load matrix, the rotated principal factor eigenvalue and variance contribution rate, as shown in Table 2 and Table 3. After rotation, the indicators per capita GDP, per capita added value of secondary industry and per capita gross output value of industrial enterprises above designated size have a larger load on factor F1. The indicators, total retail sales of social consumer goods per capita and actual amount of foreign capital utilized per capita, have a large load on factor F2. Therefore, the factor F1 can be called an industrial driving factor, and the factor F2 can be called a consumption driving factor.

According to formula (3), common factors F1 and F2 are linear combinations represented by variables X(x1-x6), and both $\mathrm{F}$ and $\mathrm{X}$ are standardized vectors. The sample values are used to calculate the estimated factor coefficients using the least squares method or the maximum likelihood estimation method. In this paper, spss 24.0 is used to calculate the factors F1 and F2 and the score coefficients of each specific indicator. See Table 4 for details. By substituting factor score coefficient and variable value into formula (3), the scores of each factor can be obtained:

$$
\begin{aligned}
& \mathrm{F} 1=0.343 x_{1}+0.359 x_{2}+0.34 x_{3}+0.067 x_{4}+0.008 x_{5}+0.13 x_{6} \\
& \mathrm{~F} 2=0.176 x_{1}-0.06 x_{2}-0.048 x_{3}+0.553 x_{4}+0.473 x_{5}-0.252 x_{6}
\end{aligned}
$$

According to Table 2, the contribution rate of the first eigenvalue after rotation is 0.43597 , and that of the second eigenvalue is 0.26584 . With the first eigenvalue contribution rate of 0.43597 as the weight of the first main factor F1 and the second eigenvalue of 0.26584 as the weight of the second main factor F2, the total factor score of the driving force of new urbanization economic factors in cities and counties is obtained, that is, $\mathrm{F}=(0.43597 \mathrm{~F} 1+$ $0.26584 \mathrm{~F} 2) / 0.70181$, which is sorted according to the score situation, as shown in Table 5.

Similarly, the factor scores of the other four sub-system modules, i.e., the social development ability of population, resource environmental bearing capacity, public service guarantee ability and urban-rural integration and cohesion, can be obtained, as shown in Table 6.

According to the results in Table 6, Fangchenggang, Nanning and Yangjiang ranked the top three in terms of economic and market driving forces. From the specific indicators, the per capita GDP, the per capita added value of the secondary industry and the per capita gross industrial output value above designated size of Fangchenggang are significantly higher than those of other cities. From the retail sales of consumer goods, except Haikou, Nanning and Yangjiang, the overall level of the other cities and counties in the Beibu Gulf urban agglomeration is not high. Thus it is clear that neither the contribution of consumption to economic growth nor the domestic demand is insufficient. Basically, all cities and counties are mainly export-oriented economies.

In terms of population and social development, Haikou ranks first with 1.58, followed by Nanning and Yulin, with Lingao County, Chongzuo City, Zhanjiang City, Dongfang City and Qinzhou City in the last six places. The major differences between cities and counties are mainly reflected in the following three aspects: First, the differences in the level of economic development, because the income level of the residents in the cities and counties ranked in the last five places is not high, which naturally limits the improvement of the comprehensive quality of the population and the development of the society; second, low level of urbanization except for Nanning and Haikou. For example, the urbanization rates of the resident population in Qinzhou City, Chongzuo City and Lingao County are $40 \%, 39.24 \%$ and $46.16 \%$ respectively, but the urbanization rates of the registered population are only $18 \%$, $20.94 \%$ and $32.63 \%$. The large difference between the urban resident population rate and the registered urban population rate indicates that the urbanization quality of the population is not high and the rural population transfer is not smooth; third, insufficient investment in science and technology and medical and health services in the cities and counties at the bottom of the rankings in terms of the proportion of scientific and technological personnel in the total population and the proportion of health and technical personnel in the total population. All of these play an important role in the construction of population and social development. 
In terms of resources and environmental carrying capacity, Fangchenggang, Chongzuo, Yangjiang and other cities rank high, and Fangchenggang ranks first with 0.889 , indicating that it is superior to other cities in natural resources, ecological environment and green production, and the last five cities and counties are Lingao County, Haikou City, Yulin City, Beihai City and Chengmai County, which shows that these counties and cities have insufficient per capita carrying capacity of natural resources, low overall technical level of industrial production and high energy consumption of resources.

In terms of guarantee of public service, the top three cities are Haikou, Beihai and Fangchenggang, Haikou ranks first with 1.194, and the last five cities and counties are Lingao, Danzhou, Yulin, Dongfang and Qinzhou, where the per capita urban and rural per capita disposable income of these cities and counties are at a low level, and the level of economic development determines the guarantee level of public service products.

In terms of urban-rural integration and cohesion, the top three cities are Haikou, Nanning and Yangjiang, and Haikou ranks first with 1.42, indicating that they have done a good job in industrial development, ecological environment and public service guarantee, so they have strong attraction to labor, capital, industry and other production factors. The last five cities and counties are Lingao County, Dongfang City, Changjiang County, Maoming City and Chengmai County.

\subsubsection{Overall evaluation of sustainable development of new urbanization}

From the comprehensive score, the top three cities are Haikou, Fangchenggang and Nanning, with Haikou ranking first with 1.218. On the whole, the Beibu Gulf Urban Agglomeration has the strongest sustainable development capability in Fangchenggang, Nanning and Beihai in Guangxi, while Yangjiang in Guangdong has a better sustainable development capacity and Haikou is the leading city in Hainan, which is in line with the actual development. The last five cities and counties are: Lingao, Danzhou, Yulin, Dongfang and Qinzhou. Nanning has a regional GDP which is far ahead of other cities in the whole Beibu Gulf urban agglomeration and an economy which is 2.7 times as large as Haikou City, the capital city, but its new urbanization is only ranked third in the sustainable development capacity, which has a lot to do with its large population, strong protection, small per capita resources, and insufficient industrial development.

The top three cities have common characteristics: First, balanced development, with relatively balanced scores in all sub-items. For example, as for the secondary indicators, Haikou ranks first in terms of population and social development, public service guarantee and urban-rural integration, while Nanning and Fangchenggang rank high in terms of secondary indicators; second, relatively high level of economic and social development. For example, as for three-level indicators, Haikou, Nanning and Fangchenggang are in the leading position in terms of per capita GDP and income of urban and rural residents.

The characteristics of the last five cities (counties): First, structural imbalance, that these cities and counties have higher scores on some indicators but lower scores on some indicators; second, insufficient driving force of export and consumption, which is at the bottom level from several specific indicators such as GDP per capita, total social consumer goods per capita and export per capita, consistent with the ranking position of these indicators in terms of overall ranking; third, low level of public service guarantee ability that the lower ranking cities and counties have shortcomings in the supply guarantee of public service products.

In order to achieve healthy and sustainable development in Beibu Gulf urban agglomeration, it is necessary to solve the problems of insufficient economic market drive, poor export and unbalanced development.

\section{Table}

Table 1 Evaluation indicator system for sustainable development capacity of new urbanization

\begin{tabular}{|c|l|l|c|c|}
\hline Overall indicator & Secondary indicators & Specific indicators & Code & Nature \\
\hline Sustainable & Economic market & Per capita GDP (yuan/person) & X1 & + \\
\hline
\end{tabular}

ISSN: 0010-8189

(C) CONVERTER 2020 
CONVERTER MAGAZINE

Volume 2021, No. 3

\begin{tabular}{|c|c|c|c|c|}
\hline \multirow[t]{26}{*}{$\begin{array}{l}\text { development capacity } \\
\text { of new urbanization }\end{array}$} & \multirow[t]{5}{*}{ driving force } & $\begin{array}{l}\text { Per capita added value of secondary } \\
\text { industry (yuan/person) }\end{array}$ & $\mathrm{X} 2$ & + \\
\hline & & 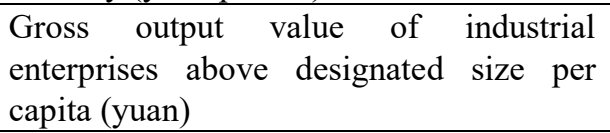 & $\mathrm{X} 3$ & + \\
\hline & & $\begin{array}{l}\text { Total retail sales of social consumer } \\
\text { goods per capita (yuan/person) }\end{array}$ & $\mathrm{X} 4$ & + \\
\hline & & $\begin{array}{l}\text { Actual amount of foreign capital utilized } \\
\text { per capita (USD/person) }\end{array}$ & $\mathrm{X} 5$ & + \\
\hline & & Total export per capita (yuan/person) & $\mathrm{X} 6$ & + \\
\hline & \multirow{8}{*}{$\begin{array}{l}\text { Social development } \\
\text { power of population }\end{array}$} & $\begin{array}{l}\text { Number of students in ordinary primary } \\
\text { and secondary schools per } 10,000 \text { people } \\
\text { (person) }\end{array}$ & $\mathrm{X} 7$ & + \\
\hline & & $\begin{array}{l}\text { Number of full-time teachers in ordinary } \\
\text { primary and secondary schools per } \\
10,000 \text { people (person) }\end{array}$ & $\mathrm{X} 8$ & + \\
\hline & & $\begin{array}{l}\text { Number of employees in scientific } \\
\text { research and technical service industry } \\
\text { per } 10,000 \text { people in urban units (persons) }\end{array}$ & X9 & + \\
\hline & & $\begin{array}{l}\text { Number of health technicians per } 10,000 \\
\text { people (person) }\end{array}$ & $\mathrm{X} 10$ & + \\
\hline & & $\begin{array}{l}\text { Internet broadband access penetration rate } \\
\text { (unit/100 people) }\end{array}$ & $\mathrm{X} 11$ & + \\
\hline & & $\begin{array}{l}\text { Internet broadband access penetration rate } \\
\text { (department } / 100 \text { people) }\end{array}$ & $\mathrm{X} 12$ & + \\
\hline & & $\begin{array}{l}\text { Urbanization rate of resident population } \\
(\%)\end{array}$ & $\mathrm{X} 13$ & + \\
\hline & & $\begin{array}{l}\text { Per capita disposable income of urban } \\
\text { and rural residents (yuan/person) }\end{array}$ & $\mathrm{X} 14$ & + \\
\hline & \multirow{8}{*}{$\begin{array}{l}\text { Resource } \\
\text { environmental } \\
\text { bearing capacity }\end{array}$} & $\begin{array}{l}\begin{array}{l}\text { Per-capita average ofwater resource } \\
\left(\mathrm{m}^{3} / \text { people }\right)\end{array} \\
\end{array}$ & $\mathrm{X} 15$ & + \\
\hline & & $\begin{array}{l}\text { Per capita land and resources area } \\
\left(\mathrm{km}^{2} / \text { person }\right)\end{array}$ & $\mathrm{X} 16$ & + \\
\hline & & Park land per capita $\left(\mathrm{m}^{2}\right)$ & $\mathrm{X} 17$ & + \\
\hline & & Built-up area green coverage rate $(\%)$ & $\mathrm{X} 18$ & + \\
\hline & & Ambient air quality composite index & $\mathrm{X} 19$ & - \\
\hline & & $\begin{array}{l}\text { Energy consumption per } 10,000 \text { yuan of } \\
\text { industrial output value (ton of standard } \\
\text { coal/ } 10,000 \text { yuan) }\end{array}$ & $\mathrm{X} 20$ & - \\
\hline & & $\begin{array}{l}\text { Water consumption per } 10,000 \text { yuan GDP } \\
\left(\mathrm{m}^{3} / 10,000 \text { yuan }\right)\end{array}$ & $\mathrm{X} 21$ & - \\
\hline & & $\begin{array}{l}\text { Water consumption per } 10,000 \text { yuan of } \\
\text { industrial added value }\left(\mathrm{m}^{3} / 10,000 \text { yuan }\right)\end{array}$ & $\mathrm{X} 22$ & - \\
\hline & \multirow{5}{*}{$\begin{array}{l}\text { Guarantee of public } \\
\text { service }\end{array}$} & $\begin{array}{l}\text { The proportion of people who buy basic } \\
\text { endowment insurance for urban workers } \\
\text { to the total population (\%) }\end{array}$ & $\mathrm{X} 23$ & + \\
\hline & & $\begin{array}{l}\text { The proportion of people who buy } \\
\text { unemployment insurance to the total } \\
\text { population (\%) }\end{array}$ & $\mathrm{X} 24$ & + \\
\hline & & $\begin{array}{l}\text { The proportion of public health } \\
\text { expenditure to GDP (\%) }\end{array}$ & $\mathrm{X} 25$ & + \\
\hline & & $\begin{array}{l}\text { The ratio of public finance expenditure on } \\
\text { education to GDP }(\%)\end{array}$ & $\mathrm{X} 26$ & + \\
\hline & & $\begin{array}{l}\text { The proportion of public finance } \\
\text { expenditure on science and technology to }\end{array}$ & $\mathrm{X} 27$ & + \\
\hline
\end{tabular}

ISSN: 0010-8189 
CONVERTER MAGAZINE

Volume 2021, No. 3

\begin{tabular}{|c|c|c|c|c|}
\hline & & GDP (\%) & & \\
\hline & & $\begin{array}{l}\text { Per capita daily living water consumption } \\
\text { (L) }\end{array}$ & $\mathrm{X} 28$ & + \\
\hline & & $\begin{array}{l}\text { Popularization rate of mobile telephones } \\
\text { (unit / } 100 \text { people) }\end{array}$ & $\mathrm{X} 29$ & + \\
\hline & & $\begin{array}{l}\text { Per capita possession of public library } \\
\text { collections (books) }\end{array}$ & $\mathrm{X} 30$ & + \\
\hline & \multirow{10}{*}{$\begin{array}{l}\text { Urban-rural } \\
\text { integration } \\
\text { cohesion }\end{array}$} & Net population inflow rate $(\%)$ & $\mathrm{X} 31$ & + \\
\hline & & $\begin{array}{l}\text { The proportion of total wages of } \\
\text { employees in urban units to GDP }(\%)\end{array}$ & $\mathrm{X} 32$ & + \\
\hline & & $\begin{array}{l}\text { The proportion of the added value of the } \\
\text { tertiary industry to GDP }(\%)\end{array}$ & $\mathrm{X} 33$ & + \\
\hline & & $\begin{array}{l}\text { The proportion of the added value of the } \\
\text { tertiary industry to GDP }(\%)\end{array}$ & $\mathrm{X} 34$ & + \\
\hline & & $\begin{array}{llll}\text { The proportion of foreign direct } \\
\text { investment in GDP }(\%)\end{array}$ & $\mathrm{X} 35$ & + \\
\hline & & Regional openness & $\mathrm{X} 36$ & + \\
\hline & & $\begin{array}{l}\text { The proportion of total retail sales of } \\
\text { social consumer goods in GDP }(\%)\end{array}$ & $\mathrm{X} 37$ & + \\
\hline & & $\begin{array}{l}\text { The proportion of real estate development } \\
\text { in GDP }(\%)\end{array}$ & $\mathrm{X} 38$ & + \\
\hline & & $\begin{array}{l}\text { Per capita sales of commercial housing } \\
\text { (yuan) }\end{array}$ & $\mathrm{X} 39$ & + \\
\hline & & $\begin{array}{l}\text { The proportion of total tourism income in } \\
\text { GDP }(\%)\end{array}$ & $\mathrm{X} 40$ & + \\
\hline
\end{tabular}

Note: Regional openness (iemport) is expressed by the ratio of total import and export volume to GDP. The more open a region is, the more it will attract labor inflow; "+"indicates a positive indicator; "-" indicates a reverse indicator

Table 2 Total Variance Explained of Economic market driving force

\begin{tabular}{|c|c|c|c|c|c|c|c|c|c|}
\hline \multirow{2}{*}{$\begin{array}{l}\text { Compon } \\
\text { ent }\end{array}$} & \multicolumn{3}{|c|}{ Initial Eigenvalues } & \multicolumn{3}{|c|}{$\begin{array}{c}\text { Extraction Sums of Squared } \\
\text { Loadings }\end{array}$} & \multicolumn{3}{|c|}{$\begin{array}{c}\text { Rotation Sums of Squared } \\
\text { Loadings }\end{array}$} \\
\hline & $\begin{array}{l}\text { Eigenval } \\
\text { ues }\end{array}$ & $\begin{array}{c}\% \text { of } \\
\text { Varian } \\
\text { ce }\end{array}$ & $\begin{array}{l}\text { Cumulativ } \\
\text { e } \%\end{array}$ & $\begin{array}{l}\text { Eigenval } \\
\text { ues }\end{array}$ & $\begin{array}{c}\% \text { of } \\
\text { Varian } \\
\text { ce }\end{array}$ & $\begin{array}{l}\text { Cumulativ } \\
\text { e } \%\end{array}$ & $\begin{array}{l}\text { Eigenval } \\
\text { ues }\end{array}$ & $\begin{array}{c}\% \text { of } \\
\text { Varian } \\
\text { ce }\end{array}$ & $\begin{array}{l}\text { Cumulativ } \\
\text { e } \%\end{array}$ \\
\hline 1 & 2.631 & $\begin{array}{c}43.85 \\
1 \\
\end{array}$ & 43.851 & 2.631 & $\begin{array}{c}43.85 \\
1 \\
\end{array}$ & 43.851 & 2.616 & $\begin{array}{c}43.59 \\
7 \\
\end{array}$ & 43.597 \\
\hline 2 & 1.58 & 26.33 & 70.181 & 1.58 & 26.33 & 70.181 & 1.595 & $\begin{array}{c}26.58 \\
4\end{array}$ & 70.181 \\
\hline 3 & 0.858 & $\begin{array}{c}14.30 \\
4\end{array}$ & 84.485 & & & & & & \\
\hline 4 & 0.576 & 9.592 & 94.077 & & & & & & \\
\hline 5 & 0.248 & 4.135 & 98.212 & & & & & & \\
\hline 6 & 0.107 & 1.788 & 100 & & & & & & \\
\hline
\end{tabular}

Extraction Method: Principal Component Analysis.

Table 3 Rotated Component Matrix of Economic market driving force

\begin{tabular}{|c|c|c|}
\hline \multirow{2}{*}{ variable } & \multicolumn{2}{|c|}{ Component } \\
\cline { 2 - 3 } & F1 & F2 \\
\hline Per capita GDP(x1) & 0.874 & -238 \\
\hline Per capita added value of secondary industry(x2) & 0.948 & -0.14 \\
\hline $\begin{array}{c}\text { Gross output value of industrial enterprises above } \\
\text { designated size per capita(x3) }\end{array}$ & 0.896 & -0.12 \\
\hline
\end{tabular}

ISSN: 0010-8189

(C) CONVERTER 2020

Www.converter-magazine.info 


\begin{tabular}{|c|c|c|}
\hline $\begin{array}{c}\text { Total retail sales of social consumer goods per } \\
\text { capita(x4) }\end{array}$ & 0.105 & 0.873 \\
\hline $\begin{array}{c}\text { Actual amount of foreign capital utilized per } \\
\text { capita(x5) }\end{array}$ & -0.039 & 0.753 \\
\hline Total export per capita(x6) & 0.372 & -0.418 \\
\hline
\end{tabular}

Table 4 Component Score Coefficient Matrix

of Economic market driving force

\begin{tabular}{|c|c|c|}
\hline \multirow{2}{*}{ variable } & \multicolumn{2}{|c|}{ Component } \\
\cline { 2 - 3 } & F1 & 0.176 \\
\hline Per capita GDP(x1) & 0.343 & -0.06 \\
\hline Per capita added value of secondary industry(x2) & 0.359 & -0.048 \\
\hline $\begin{array}{c}\text { Gross output value of industrial enterprises above } \\
\text { designated size per capita(x3) }\end{array}$ & 0.34 & 0.553 \\
\hline $\begin{array}{c}\text { Total retail sales of social consumer goods per } \\
\text { capita(x4) }\end{array}$ & 0.067 & 0.473 \\
\hline $\begin{array}{c}\text { Actual amount of foreign capital utilized per } \\
\text { capita(x5) }\end{array}$ & 0.008 & -0.252 \\
\hline
\end{tabular}

Table 5 Economic market drivers score and ranking

\begin{tabular}{|c|c|c|c|c|c|c|}
\hline City and county & F1 Score & Ranking & F2 Score & Ranking & $\begin{array}{c}\text { The total score } \\
\text { of F }\end{array}$ & Ranking \\
\hline Nanning & 0.20127 & 4 & 0.79298 & 3 & 0.43 & 5 \\
\hline Beihai & 1.67395 & 2 & -0.12799 & 7 & 0.99 & 2 \\
\hline Fangchengang & 2.37559 & 1 & -0.43902 & 9 & 1.31 & 1 \\
\hline Qinzhou & -0.35639 & 11 & 0.48561 & 4 & -0.04 & 7 \\
\hline Yulin & -1.10387 & 13 & -0.55456 & 11 & -0.9 & 13 \\
\hline Chongzuo & 0.47185 & 3 & -1.69455 & 15 & -0.35 & 11 \\
\hline Zhangjiang & -0.47866 & 12 & 0.16983 & 6 & -0.23 & 10 \\
\hline Maoming & -0.10926 & 9 & 0.30105 & 5 & 0.05 & 6 \\
\hline Yangjiang & -0.04677 & 8 & 2.26112 & 1 & 0.83 & 3 \\
\hline Haikou & 0.07298 & 7 & 1.67315 & 2 & 0.68 & 4 \\
\hline Danzhou & -1.34291 & 15 & -0.46173 & 10 & -1.01 & 14 \\
\hline Dongfang & -0.33344 & 10 & -0.71825 & 14 & -0.48 & $12 \mathrm{~s}$ \\
\hline Chengmai & 0.16725 & 5 & -0.40515 & 8 & -0.05 & 8 \\
\hline Lingao & -1.31853 & 14 & -0.64122 & 12 & -1.06 & 15 \\
\hline Changjiang & 0.12692 & 6 & -0.64129 & 13 & -0.16 & 9 \\
\hline
\end{tabular}

Table 6 Score and ranking of sustainable development ability of regional new urbanization

\begin{tabular}{|c|c|c|c|c|c|c|c|c|c|c|c|c|}
\hline & $\begin{array}{c}\text { Econ } \\
\text { omic } \\
\text { mark } \\
\text { et } \\
\text { county } \\
\text { drivin } \\
\text { g } \\
\text { force }\end{array}$ & $\begin{array}{c}\text { Ran } \\
\text { king }\end{array}$ & $\begin{array}{c}\text { develo } \\
\text { pment } \\
\text { power } \\
\text { of } \\
\text { populat } \\
\text { ion }\end{array}$ & $\begin{array}{c}\text { Ran } \\
\text { king }\end{array}$ & $\begin{array}{c}\text { Resourc } \\
\text { environ } \\
\text { mental } \\
\text { bearing } \\
\text { capacity }\end{array}$ & $\begin{array}{c}\text { Ran } \\
\text { king }\end{array}$ & $\begin{array}{c}\text { Guara } \\
\text { ntee } \\
\text { of } \\
\text { publi } \\
\text { c } \\
\text { servic } \\
\text { e }\end{array}$ & $\begin{array}{c}\text { Ran } \\
\text { king }\end{array}$ & $\begin{array}{c}\text { Urban } \\
\text {-rural } \\
\text { integr } \\
\text { ation } \\
\text { and } \\
\text { cohesi } \\
\text { on }\end{array}$ & $\begin{array}{c}\text { Ran } \\
\text { king }\end{array}$ & $\begin{array}{c}\text { Comp } \\
\text { osite } \\
\text { scores }\end{array}$ & $\begin{array}{c}\text { Ran } \\
\text { king }\end{array}$ \\
\hline Nanning & 0.43 & 5 & 1.37 & 2 & -0.247 & 9 & 0.625 & 4 & 0.83 & 2 & 0.857 & 3 \\
\hline Beihai & 0.99 & 2 & 0.12 & 5 & -0.316 & 12 & 0.708 & 2 & 0.08 & 7 & 0.604 & 5 \\
\hline $\begin{array}{c}\text { Fangche } \\
\text { ngang }\end{array}$ & 1.31 & 1 & 0.15 & 4 & 0.889 & 1 & 0.64 & 3 & 0.27 & 4 & 1.136 & 2 \\
\hline Qinzhou & -0.04 & 7 & -0.36 & 11 & 0.0001 & 8 & - & 11 & -0.11 & 9 & -0.252 & 11 \\
\hline
\end{tabular}

ISSN: 0010-8189 


\begin{tabular}{|c|c|c|c|c|c|c|c|c|c|c|c|c|}
\hline Yulin & -0.9 & 13 & 0.28 & 3 & -0.339 & 13 & 0.711 & 13 & 0.1 & 6 & -0.642 & 13 \\
\hline $\begin{array}{c}\text { Chongz } \\
\text { uo }\end{array}$ & -0.35 & 11 & -0.55 & 14 & 0.875 & 2 & 0.175 & 10 & 0.13 & 5 & 0.002 & 6 \\
\hline $\begin{array}{c}\text { Zhangji } \\
\text { ang }\end{array}$ & -0.23 & 10 & -0.41 & 13 & 0.1 & 7 & $\begin{array}{c}- \\
0.086 \\
\end{array}$ & 8 & -0.02 & 8 & -0.179 & 9 \\
\hline $\begin{array}{c}\text { Maomin } \\
\mathrm{g}\end{array}$ & 0.05 & 6 & -0.29 & 8 & 0.201 & 6 & -0.15 & 9 & -0.29 & 12 & -0.125 & 8 \\
\hline $\begin{array}{c}\mathrm{Y} \\
\text { angjiang }\end{array}$ & 0.83 & 3 & -0.1 & 7 & 0.595 & 3 & 0.26 & 5 & 0.29 & 3 & 0.665 & 4 \\
\hline Haikou & 0.68 & 4 & 1.58 & 1 & -0.825 & 14 & 1.194 & 1 & 1.42 & 1 & 1.218 & 1 \\
\hline $\begin{array}{c}\text { Danzho } \\
\mathrm{u}\end{array}$ & -1.01 & 14 & -0.32 & 10 & -0.251 & 10 & $\begin{array}{c}- \\
0.726 \\
\end{array}$ & 14 & -0.19 & 10 & -0.867 & 14 \\
\hline $\begin{array}{c}\text { Dongfan } \\
\mathrm{g}\end{array}$ & -0.48 & 12 & -0.38 & 12 & 0.294 & 5 & $\begin{array}{c}- \\
0.549 \\
\end{array}$ & 12 & -0.65 & 14 & -0.58 & 12 \\
\hline $\begin{array}{c}\text { Chengm } \\
\text { ai }\end{array}$ & -0.05 & 8 & -0.29 & 9 & -0.31 & 11 & 0.098 & 6 & -0.28 & 11 & -0.217 & 10 \\
\hline Lingao & -1.06 & 15 & -0.79 & 15 & -1.152 & 15 & $0 . \overline{759}$ & 15 & -0.99 & 15 & -1.513 & 15 \\
\hline $\begin{array}{c}\text { Changji } \\
\text { ang }\end{array}$ & -0.16 & 9 & -0.03 & 6 & 0.486 & 4 & -0.04 & 7 & -0.59 & 13 & -0.107 & 7 \\
\hline
\end{tabular}

\section{Conclusions}

In this paper, the issue of sustainable development of Beibu Gulf urban agglomerations in in the context of novel Urbanization was discussed by collecting the relevant data of Guangxi Statistical Yearbook, Hainan Statistical Yearbook and Guangdong Statistical Yearbook in 2019, and constructing the evaluation indicator system of sustainable development of cities and counties. The evaluation model was established by using principal component analysis, and 40 specific indicators were selected from five dimensions of economic drive, population and social development, resources and environment, public service guarantee and regional agglomeration power for comparative evaluation, which provided theoretical ideas for the selection of evaluation indicators of sustainable development level of new urbanization in urban agglomerations. Based on the scores and rankings of each dimension of sustainable development level of each city after evaluation, the common characteristics of the cities and counties with the top and bottom rankings are sorted out.

In view of the current urbanization situation of Beibu Gulf urban agglomeration, in the future urbanization process, focus should be put on the connotation of new urbanization, starting from the concept of sustainable development, to promote the new urbanization work from the aspects of economic development, population society, resources and environment, public services, etc., and take the market as the guide to enhance the level of economic development and enhance the driving force of urban development. The inter-regional industrial linkage should be strengthened, and the regional economy should be developed according to the resource endowments and characteristics of cities and counties. Urbanization and rural revitalization should be promoted simultaneously, and urbanization should be promoted with the concept of cultural diversity and integration, so as to promote the symbiotic development of large, medium and small cities and small towns. The science and technology should be applied to improve the efficiency of resource utilization, protect the ecological balance and continue to promote the construction of the blue ecological bay area. People-orientation should be adhered to and social security work should be done well to remove the worries of the transferred agricultural population.

\section{References}

[1] H.J. Fan, H.H. Hu, "Evaluation model of urbanization and its application", Journal of Hebei University of Economics and Business, vol.34, no. 3, pp. 33-38, 2013. 
[2] Mohammad. B, "using innovation research to achieve sustainability in urban developments: The case of Masdar", International Journal of Technology Management \& Sustainable Development, vol.12, no.1, pp. 3-14, 2013.

[3] C. Roberta., C Roberto, "Beyond Optimal City Size: An Evaluation of Alternative Urban Growth Patterns", Urban Studies, vol.37, no. 9, pp.1479-1496, 2000.

[4] D. Didier, A. Elizabeth, "The new towns around Paris 40 years late: New dynamic centralities or suburbs facing risk of marginalization?," Urban Studies, vol. 54, no.4, pp. 862-877, 2017.

[5] M. Lu, "Great Cities in great power: Unification, development and balance of contemporary China," Shanghai: Shanghai People's Publishing House Press, pp. 30-275, 2016.

[6] H. Han, L.L. Fu, "Evaluation of Urbanization Efficiency for Coastal Port Cities in China", Journal of Coastal Research, no. 98, pp. 335-338, 2019.

[7] Z.Z. Han, "Research on the evaluation of new urbanization process in Guangdong," Forward Position or Economics, no. 3, pp. 93-101, 2013.

[8] Éva. K, "City success index, urban development, a possible method to research urban strategy", POLLACK PERIODICA An International Journal for Engineering and Information Sciences, vol. 11, no. 3, pp. 27-42, 2016. 